\title{
PENGARUH PANJANG SERAT DAN FRAKSI VOLUME TERHADAP KEKUATAN IMPACT DAN BENDING MATERIAL KOMPOSIT POLYESTER- FIBER GLASS DAN POLYESTER-PANDAN WANGI
}

\author{
Emmy Dyah S*., Nasmi Herlina Sari**, IGNK Yudhyadi***, Sinarep****,Topan \\ $*, * *, * * *, * * *$ Dosen Fakultas Teknik Universitas Mataram \\ Jalan. Majapahit No. 62 Mataram \\ Email: nazmi2707@yahoo.com
}

\begin{abstract}
At this research by using two kinds of composite that is composite of fibre of screw pine of fragrant and composite of glass fibre. And in doing research will be done by two examination type that is test the strength bending and test the strength impact. How strength from two composite type of examinee with the long variation and fibre volume to be used.

As the result test the strength of impact and bending to be composite of screw pine of fragrant with the long variation of fibre with the random fibre direction that composite highest strength impact of fibre of screw pine of fragrant got at fibre length $5 \mathrm{~cm}$ of equal to 2286,67 sing / $/ \mathrm{m}^{2}$. while for the variation of volume of highest strength impact fibre there are at fibre volume $40 \%$ with the unidirectional fibre direction equal to 2940 $\mathrm{Kj} / \mathrm{m}^{2}$. While to result of composite strength bending test of screw pine of fragrant got by biggest strength bending with the long variation of fibre with the direction of fibre random, gotten at fibre length $5 \mathrm{~cm}$ of equal to 146,67 KN . while for the strength of bending with the variation of fibre volume with the unidirectional fibre direction, highest strength bending got at fibre volume $40 \%$ equal to 236,67 KN. Medium to result of composite strength impact test of glass fibre at long variation of highest strength fibre got at length seart $5 \mathrm{~cm}$ of equal to $5553,33 \mathrm{Kj} / \mathrm{m}^{2}$. While strength impact with the variation of biggest strength fibre volume at fibre volume $40 \%$ with the unidirectional fibre direction equal to $15908,67 \mathrm{Kj} / \mathrm{m}^{2}$. Medium at composite strength bending test of glass fibre with the long variation of fibre where fibre direction is random of biggest kerkutan bending at fibre length $5 \mathrm{~cm}$ of equal to $263,33 \mathrm{KN}$. while to result of kekutan bending at variation of fibre volume got by biggest strength bending at fibre volume $40 \%$ equal to $278,34 \mathrm{KN}$.
\end{abstract}

Keyword: Pandanus Amaryllifolius, bending tes, impact tes, resin, fiber glass.

\section{Pendahuluan}

Serat alami sekarang banyak digunakan karena jumlahnya banyak dan sangat murah jadi sering dimanfaatkan sebagai material penguat seperti serat pandan wangi Pandanus amaryllifolius Roxb, kenaf, abaca, rosella, jerami dan masih banyak serat alami yang lain yang biasa dimanfaatkan, akan tetapi serat alami mempunyai kekuatuan yang rendah dibandingkan serat buatan. Menurut sentra informasi iptek (2009) Pandan wangi yang dalam bahasa latinnya Pandanus amaryllifolius Roxb, tumbuh liar di daerah tropis. Kadang-kadang di pinggir sungai, di tepi rawa atau di tanah yang basah. Subur di daerah pantai sampai ketinggian 500 meter di atas permukaan laut. Batangnya bulat dengan bekas duduk daun, bisa bercabang-cabang, menjalar, akar tunjang ke luar di sekitar pangkal batang dan cabang. Daun tunggal, duduk, dengan pangkal memeluk batang, tersusun berbaris tiga dalam garis spiral. Helai daun berbentuk pita, tipis, licin, ujung runcing, tepi rata. Bagi tanaman yang subur, daunnya bisa mencapai pajang antara 40 sampai $80 \mathrm{~cm}$, lebar 3 sampai 5 $\mathrm{cm}$, warna hijau, bila diremas berbau harum. Bunga majemuk, bongkol, putih. Buahnya batu, menggantung, bentuk bola, warna jingga. Memperbanyak tumbuhan pandan bisa dilakukan dengan memisahkan tunas-tunas muda yang tumbuh diantara akar-akarnya.

Serat yang digunakan dalam penelitian ini yaitu dengan mengunakan serat pandan wangi (Pandanus amaryllifolius Roxb) sebagai bahan alternative pembanding atar serat buatan, serat buatan yang dipakai dalam penelitian ini adalah serat fiber glass, karena serat ini banyak ditemukan dimana-mana dan paling banyak digunakan dalam pembuatan barang-barang produksi seperti yang disebutkan diatas. Dan serat buatan yang digunakan dalam pengujian ini adalah Serat gelas dibuat dari campuran kaolin, sand, colemantie, limestone yang dilebur dalam furnace electrically heated bushing. Selanjutnya, cairan material tersebut ditarik dalam bentuk filamen (serat) dengan diameter 5-24 mm dan ditaburkan di atas belt conveyor dengan 
orientasi acak. Serat acak tersebut diikat oleh pengikat organik polyvinil acetate untuk menghasilkan ikatan longgar mat terbuka yang untuk dilakukan laminasi. Tipe serat gelas yang paling banyak digunakan di industri adalah E-glass baik berbentuk random chopped strand mat (CSM) maupun woven roving.

Sulistijono (2008) tentang analisa pengaruh fraksi volume serat kelapa pada komposit matriks polyester terhadap kekuatan tarik, impact dan bending menunjukkan bahwa serat kelapa yang dikombinasikan dengan polyester sebagai matrik akan dapat menghasilkan komposit alternatif yang salah satunya berguna sebagai duduk bantal mobil, papan/meja. Dengan memvariasikan fraksi volume serat kelapa, diharapkan akan didapatkan kekuatan tarik, impact dan bending komposit yang maksimal untuk mendukung pemanfaatan komposit alternative.

Berdasarkan uraian diatas timbul pemikiran untuk menganalisis kekuatan impact komposit polyesterfiber glass dan polyester- pandan wangi. Tujuan penelitian ini Adapun tujuan dilakukanya penelitian ini adalah : untuk mengetahui kekuatan impact dan bending material komposit polyester-fiber galss dan polyester- pandan wangi. Dan membandingkan kedua sifat dari tipe material komposit tersebut. Sedangkan manfaat peelitian ini adalah Secara praktis dapat dipakai sebagai bahan pertimbangan bagi bidang industri untuk menggunakan kompositb sebagai salah satu bahan pengganti material konstruksi.

\section{Dasar Teori}

\section{Bahan Komposit}

Bahan komposit pada umumnya terdiri dari dua unsur, yaitu serat (fiber) sebagai bahan pengisi dan bahan pengikat serat-serat tersebut yang disebut matrik. Didalam komposit unsur utamanya adalah serat, sedangkan bahan pengikatnya menggunakan bahan polimer yang mudah dibentuk dan mempunyai daya pengikat yang tinggi. Pengunaan serat sendiri yang utama untuk menentukan karakteristik bahan komposit, seperti : kekakuan, kekuatan serta sifat-sifat mekanik yang lainnya.

Salah satu keuntungan material komposit adalah kemampuan material tersebut untuk diarahkan sehingga kekuatannya dapat diatur hanya pada arah tertentu yang kita kehendaki, hal ini dinamakan "tailoring properties" dan ini adalah salah satu sifat istimewa komposit yaitu ringan, kuat, tidak terpengaruh korosi, dan mampu bersaing dengan logam, dengan tidak kehilangan karakteristik dan kekuatan mekanisnya.

Pemanfatan pandan wangi selain sebagai rempah-rempah juga digunakan sebagai bahan baku pembuatan minyak wangi. Daunnya sering digunakan sebagai bahan penyedap, pewangi dan pemberi warna hijau pada masakan atau penganan.

Untuk menentukan serat sebagai bahan pengisi komposit harus dilakukan pengujian tarik serat yang akan digunakan seperti terlihat pada tabel 2.1 dan 2.2.

Tabel .1 Hasil pengujian serat tanpa perlakuan alkali

\begin{tabular}{|l|l|l|l|l|}
\hline No & $\begin{array}{l}\text { F Gaya } \\
(\mathrm{N})\end{array}$ & $\begin{array}{l}\text { Diameter Serat } \\
(\mathrm{mm})\end{array}$ & $\begin{array}{l}\text { Luas Penampang } \\
\left(\mathrm{mm}^{2}\right)\end{array}$ & $\begin{array}{l}\text { Kekuatan Tarik } \\
(\mathrm{Mpa})\end{array}$ \\
\hline 1 & 5,8 & 0,88 & 0,60 & 9,64 \\
\hline 2 & 2,1 & 0,63 & 0,31 & 6,84 \\
\hline 3 & 4,4 & 0,72 & 0,41 & 10,84 \\
\hline 4 & 2,9 & 0,69 & 0,37 & 7,81 \\
\hline 5 & 1,8 & 0,53 & 0,22 & 8,12 \\
\hline \multicolumn{2}{|l}{ Rata-rata } & 8,69 \\
\hline
\end{tabular}

Sumber : Pangujian di laboratorium Bahan Teknik Fakultas Teknik Universitas Gadjah Mada

Tabel 2. Hasil pengujian serat dengan perlakuan alkali

\begin{tabular}{|l|l|l|l|l|}
\hline No & $\begin{array}{l}\text { F Gaya } \\
(\mathrm{N})\end{array}$ & $\begin{array}{l}\text { Diameter Serat } \\
(\mathrm{mm})\end{array}$ & $\begin{array}{l}\text { Luas Penampang } \\
\left(\mathrm{mm}^{2}\right)\end{array}$ & $\begin{array}{l}\text { Kekuatan Tarik } \\
(\mathrm{Mpa})\end{array}$ \\
\hline 1 & 23,6 & 0,81 & 0,52 & 45,50 \\
\hline 2 & 19,4 & 0,69 & 0,37 & 52,24 \\
\hline 3 & 10,3 & 0,66 & 0,34 & 30,44 \\
\hline 4 & 17,5 & 0,78 & 0,48 & 36,49 \\
\hline 5 & 8,5 & 0,59 & 0,28 & 30,69 \\
\hline \multicolumn{2}{|l}{ Rata-rata } & 39,072 \\
\hline
\end{tabular}

Sumber : Data Pangujian di laboratorium Bahan Teknik Fakultas Teknik Universitas Gadjah Mada 
Serat gelas mempunyai karakteristik yang berbeda-beda. Pada penggunaannya, serat gelas disesuaikan dengan sifat/karakteristik yang dimilikinya. Serat gelas terbuat dari silica, alumina, lime, magnesia dan lain-lain. Biaya produksi rendah, proses produksi sangat sederhana, memberikan serat gelas unggul ratio (perbandingan) harga dan performance. Serat gelas banyak digunakan di industri-industri otomotif seperti pada panel-panel body kendaraan. Bahkan sepeda motor sekarang seluruh body terbuat dari komposit yang berpenguat serat gelas. Komposit glass/epoxy dan glass/polyester diaplikasikan juga pada lambung kapal dan bagian-bagian pesawat terbang.

\section{Metodologi Penelitian}

Proses pengambilan serat pandan wangi

a. Pengambilan daun pandan wangi dari pohon

b. Daun pandan wangi dicuci dengan air agar debu-debu yang menempel hilang

c. Pengambilan serat daun pandan wangi dilakukan dengan cara direndam dalam lumpur selama 9 hari.

d. Serat pandan wangi yang didapat dicuci hingga bersih

e. Serat pandan wangi yang didapat dikeringkan dengan cara diangin-anginkan.

f. Serat yang telah didapat siap untuk dilakukan perlakuan alkali (perendaman dengan $\mathrm{NaOH} 4 \%$ ).

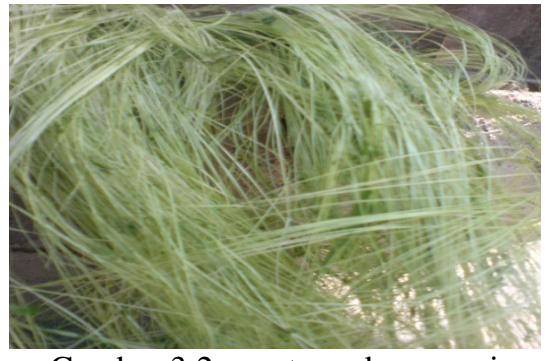

Gambar 3.2. serat pandan wangi

\section{Perlakuan serat}
a. Serat yang telah disiapkan kemudian direndam dalam larutan $\mathrm{NaOH}$ dengan konsentrasi larutan $4 \%$ selama 1,5 jam
b. Setelah selesai direndam, kemudian serat dicuci dengan air mineral.
c. Kemudian serat dikeringkan.

\section{Pembuatan cetakan}

Untuk pengujian impact cetakan dibuat menggunakan kaca dengan ketebalan $15 \mathrm{~mm}$ dengan ukuran mengacu pada standar spesimen uji impact
ASTM D265 yang mempunyai daerah pencetakan 60 $\times 15 \mathrm{~mm}$ dengan tebal spesimen $10 \mathrm{~mm}$.

\section{Proses pembuatan benda uji yang menggunakan resin polyester}

a. Alat dan bahan dipersiapkan dahulu

b. Tahap awal yaitu pengolesan wax mold release atau kit mobil pada cetakan untuk memudahkan pengambilan benda uji dari cetakan.

c. Tuangkan polyester dan katalis sesuai perhitungan yang telah ditentukan ke dalam gelas pencampur kemudian aduk hingga campuran tersebut merata.

d. Tuangkan serat sebanyak $30 \%$ volume ke dalam campuran polyester dan katalis, kemudian aduk hingga campuran serat dan polyester tercampur secara merata, kemudian campuran tersebut dituang ke dalam cetakan dan diatur supaya merata dalam cetakan.

e. Penutupan dengan menggunakan kaca yang bertujuan agar void yang kelihatan dapat diminimalkan jumlahnya yang kemudian dilakukan pengepresan dengan menggunakan batu penekan.

f. Proses pengeringan dibawah sinar matahari, proses ini dilakukan sampai benar-benar kering yaitu 5-10 jam dan apabila masih belum benar-benar kering maka proses pengeringan dapat dilakukan lebih lama

g. Proses pengambilan komposit dari cetakan yaitu menggunakan pisau ataupun cutter.

h. Benda uji komposit siap untuk dibentuk menjadi spesimen benda uji.

\section{Analisa dan pembahasan \\ Kekuatan Impact}

Dari tabel 4.1 diperoleh grafik hubungan kekuatan impact dengan variasi volume serat komposit pandan wangi dan komposit serat gelas. Dapat dilihat seperti ditunjukkan pada gambar 4.1.

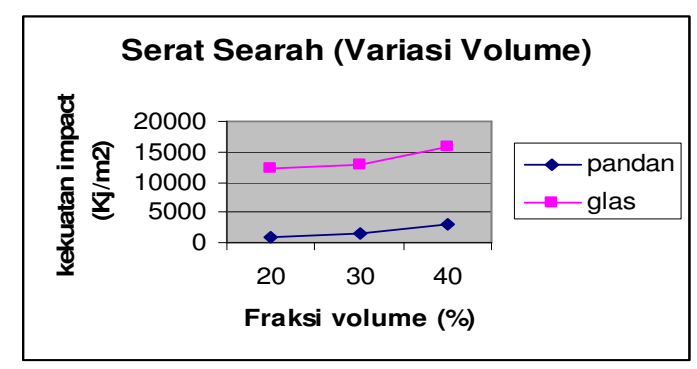


Gambar . 4.1. Grafik hubungan kekuatan impact dengan variasi volume serat komposit pandan wangi dan komposit serat gelas.

Seperti terlihat pada gambar 4.1 dimana dengan bertambahnya fraksi volume serat kekuatan impact juga akan semakin bertambah, seperti hasil uji kekuatan impact komposit serat pandan wangi, didapat kekuatan impact paling rendah pada volume serat $20 \%$ sebesar $980 \mathrm{Kj} / \mathrm{m}^{2}$, ini dipengaruhi oleh banyaknya serat yang digunakan dalam menahan beban yang diberikan oleh matrik. Disamping itu adanya pergeseran serat yang terjadi pada specimen, pada saat dilakuakan pengujian impact menyebabkan specimen tidak mampu merima energi yang diberikan. Sehingga cepat terjadi patah. Dimana bentuk patahannya seperti dalam gambar 4.2 dibawah ini.

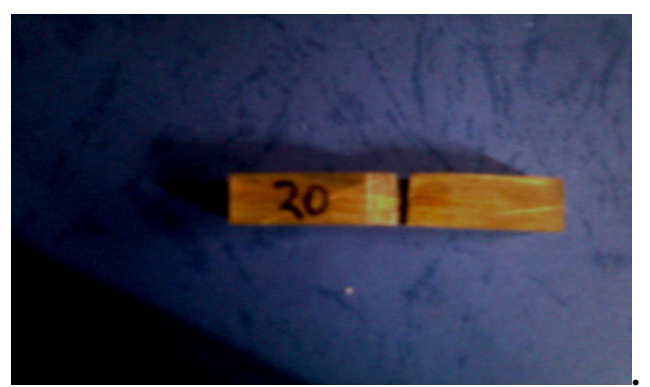

Gambar 4.2 Foto makro specimen uji impact dengan volume serat $20 \%$

Dari gambar 4.1 juga terlihat bahwa komposit dengan serat pandan wangi untuk fraksi volume $30 \%$ menunjukkan bahwa kekuatan impact sebesar 12968,667 Kj/m². lebih kuat dari komposit dengan fraksi volume $20 \%$ hal ini terjadi karena jumlah serat yang digunakan lebih banyak, sehingga lebih mampu menerima energi yang diberikan lebih besar. Dimana hasil specimen setelah dilakukan uji kekuatan impact dapat dilihat pada gambar di bawah ini.

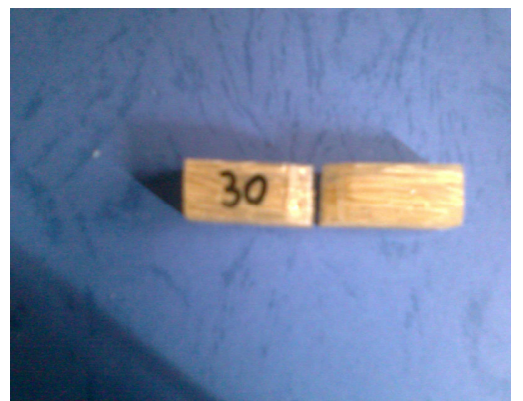

Gambar 4.4 Foto makro specimen dengan serat selanjutnya, untuk komposit serat pandan wangi dengan fraksi volume serat $40 \%$ didapat kekuatan impactnya $2940 \mathrm{Kj} / \mathrm{m}^{2}$. pada spesimen dengan serat pandan wangi, disini terjadi penambahan kekuatan dibandinggkan dengan volume serat $20 \%$ dan $30 \%$, ini dikarenakan lebih padatnya spesimen yang terisi dengan serat, hal ini menandakan kalau semakin banyaknya serat yang dipakai maka pengaruhnya terhadap kekuatan dari spesimen itu sendiri juga besar, dan kemungkinan untuk bergesernya serat akan kecil pada saat mendapat beban sehingga lebih bisa untuk menahan beban.

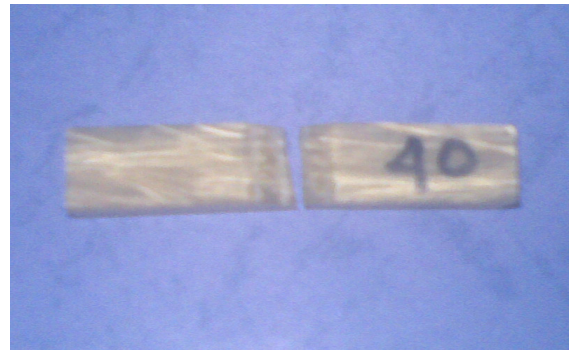

Gambar 4.6 Foto makro hasil uji impact dengan volume serat $40 \%$

Pada specimen dengan serat gelas, kekuatan impactnya bertambah dengan bertambahya volume serat yang digunakan, seperti terlihat pada gambar 4.1. dari hasil uji impact pada specimen dengan serat gelas didapat kekuatn impact terendah pada specimen dengan volume serat $20 \%$ sehingga didapat kekuatan impactnya sebesar12315,34 Kj/m², ini dikarenakan jumlah serat yang digunakn untuk menahan beban yang diberikan oleh matrik lebih sedikit sehingga kemampuan pada specimen dalam menahan beban juga berkurang, seperti terlihat pada gambar dibawah ini terlihat jelas bahwa spesimenya kelihatan getas karena kurangnya serat atau penguat yang digunakan.

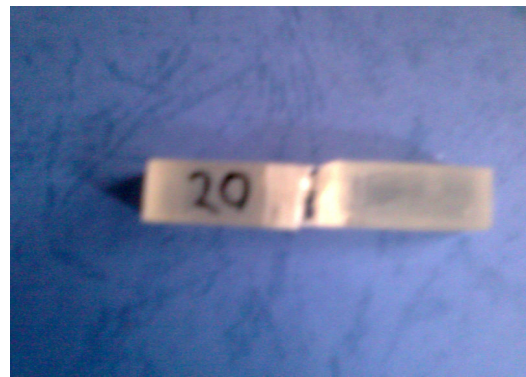

Gambar 4.3. Foto makro specimen serat gelas dengan volume serat $20 \%$

Dari gambar 4.1 juga dilihat bahwa untuk specimen dengan serat gelas juga mengalami pertambahan kekuatan dengan bertambahnya volume serat yaitu sebanyak $30 \%$ dengan besar kekutan impactnya $12968,667 \mathrm{Kj} / \mathrm{m}^{2}$, dari gambar dibawah juga terlihat patahan impact memiliki tekstur yang tidak rata, ini 
menandakan bahwa komposit dengan volume serat memiliki tinggkat keuletan yang tinggi sehingga memiliki sifat ulet yang tinggi pula, dan pada saat dikenai beban akan lebih kuat.

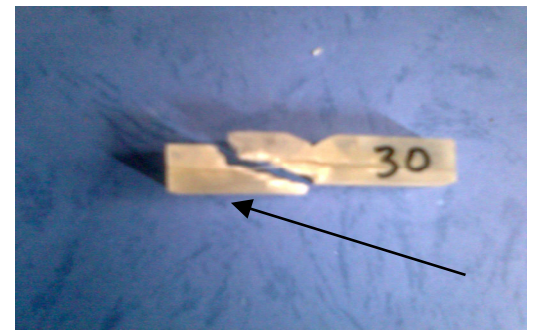

Gambar 4.5. Foto makro hasil uji kekuatan impact dengan volume serat $30 \%$

Selanjutnya, dilihat dari gambar 4.1 bahwa kekuatan impact paling tinggi didapat pada volume serat $40 \%$ sebesar $15908,67 \mathrm{Kj} / \mathrm{m}^{2}$. Ini menunjukkan bahwa Semakin banyaknya serat yang digunakan kekuatan, dan tingkat elatisitas dari spesimen juga akan bertambah, artinya sepesimen akan lebih mampu menyerap energi yang diberikan. seperti dilihat pada hasil patahan setelah dikenai beban uji kekuatan impact bentuk patahan tidak merata, ini menunjukkan kekuatan, dan keuletan dari spesimen dengan volume serat $40 \%$ paling tinggi.

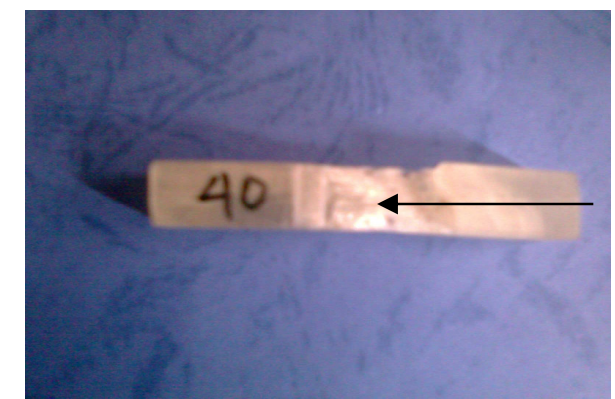

Gambar 4.7 Foto makro hasil uji impact dengan volume serat $40 \%$

Pada hasil uji kekuatan impact dengan membandingkan komposit pandan wangi dengan komposit serat gelas dapat dilihat pada gambar 4.1 gerafik hasil pengujian, bahwa 13,75 \% kekuatan impact komposit serat gelas lebih tinggi dibandingkan dengan komposit serat pandan wangi. hal ini disebabkan karena kekasaran permukaan serat gelas lebih tinggi dari pada serat pandan wangi, sehingga kemungkinan terlepas dan bergesernya serat waktu spesimen meresap energi yang diberikan serat gelas lebih kuat dan lebih mampu. Selain itu juga bahwa elastisitas dari serat gelas lebih tinggi dari pada serat pandan wangi jadi waktu menahan beban juga akan lebih kuat.

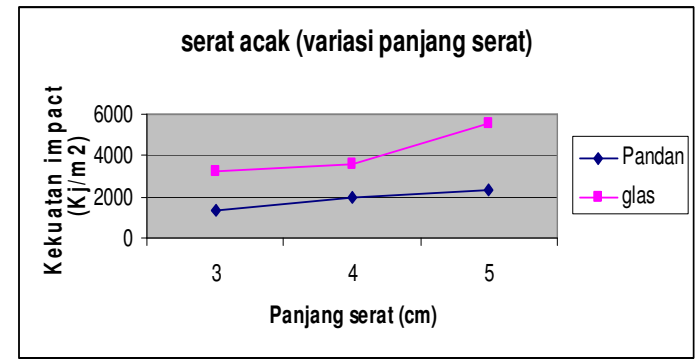

Gambar. 4.8. Grafik hubungan kekuatan impact dengan variasi panjang

serat kompositserat gelas dan komposit serat pandan wangi

Dari gambar 4.8 diatas dilihat bahwa semakin panjang serat yang dipakai maka kekuatan impactnya akan semakin tinggi. pada spesimen serat pandan wangi dengan panjang serat $3 \mathrm{~cm}$ didapat kekuatan impactnya sebesar 1306,667 Kj/m², kekuatan impact yang paling rendah ini dikarenakn pendeknya serat yang digunakan sehingga jumlah serat sebagai penguat lebih sedikit. Dan pada waktu serat menahan beban akan cepat sekali mengalami patah.

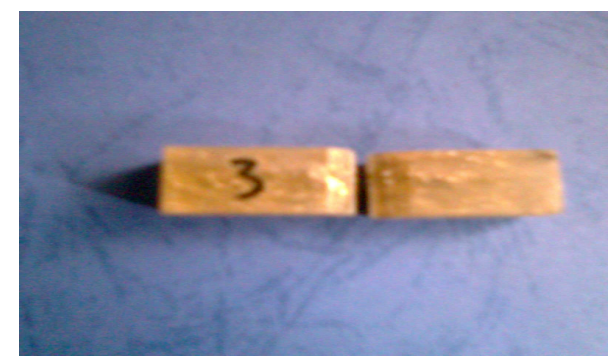

Gambar 4.9 Foto makro hasil uji impact dengan panjang seart $3 \mathrm{~cm}$

Pada gambar 4.8 juga dapat dilihat bahwa pada spesimen serat pandan wangi dengan panjang serat 4 cm dimana kekuatan impactnya adalah $1960 \mathrm{Kj} / \mathrm{m}^{2}$. Dimana kekuatan mengalami peningkatan dari pada komposit serat pandan wangi dengan panjang serat 3 $\mathrm{cm}$. Peningkatan kekuatan ini dikarenakan lebih padatnya serta yang ada dalam spesimen, sehingga pergeseran serat waktu menahan beban yang diberikan oleh matrik serat akan lebih kuat.selain itu juga jumlah ruang kosong pada spesimen dengan panjang serat $4 \mathrm{~cm}$ lebih sedikit. Seperti terlihat pada gambar 4.10. bentuk spesimenya lebih padat dan ulet karena jumlah serat yang ada pada spesimen lebih banyak. 


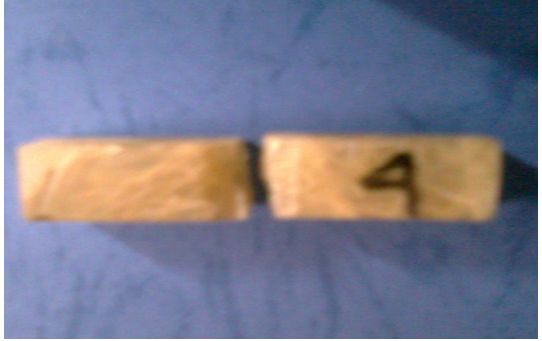

Gambar 4.10. Foto makro hasil uji impact dengan panjang serat $4 \mathrm{~cm}$

Selanjutnya, pada spesimen dengan panjang serat 5 $\mathrm{cm}$ seperti terlihat pada gambar 4.8 dibawah, dari hsil uji kekuatan impact dengan panjang serat $5 \mathrm{~cm}$ terlihat tidak ada terjadinya void, lebih ulet, dan padat, ini menujukkan bahwa semkain panjang serat tingkat kekutan impactnya akan semakin tinggi, dan keuletan dari spesimen itu sendiri akan semakin bertambah, sehingga pada saat beban diberikan pada spesimen dengan panjang serat $5 \mathrm{~cm}$ akan lebih kuat dibandingkan dengan panjang serat $3 \mathrm{~cm}$, dan $4 \mathrm{~cm}$ ini juga dikarenakan tingkat elastisitas serat yang lebih banyak akan lebih tinggi.

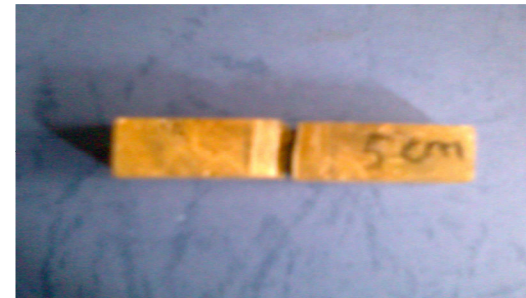

Gambar 4.11 Foto makro hasil uji impact dengan panjang serat $5 \mathrm{~cm}$

Dari gambar 4.8 dapat dilihat bahwa hasil uji kekuatan impact untuk spesimen dengan serat gelas kekuatan impact pada panjang serat $3 \mathrm{~cm}$ yaitu sebesar 3266,67 $\mathrm{Kj} / \mathrm{m}^{2}$. Ini dikarenakan tingkat elastisitas serat yang pendek lebih rendah dari pada serat yang lebih panjang, sehingga waktu menerima beban akan cepat mengalami patah. semakin pedeknya serat tinggkat kegetasan dari spesimen akan lebih tinggi, selain itu juga pergeseran serat waktu menerima beban kemungkinan besar akan terjadi. Sehingga pada saat spesimen menerima energi yang diberikan akan cepat sekali patah. Seperti terlihat pada gambar hasil uji impact dibawa ini adanya bagian pada spesimen yang belum terisi dengan serat sehingga pada saat dikenai beban akan cepat sekali patah.

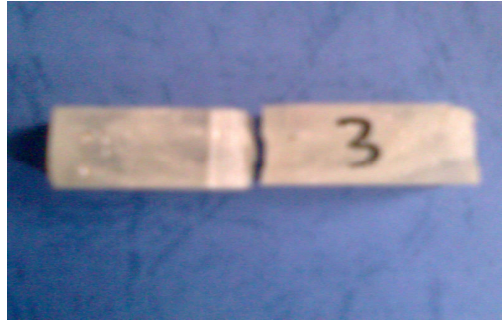

Gambar 4.12. Foto makro hasil uji impact dengan panjang serat $3 \mathrm{~cm}$

Dari gambar 4.8 juga dilihat bahwa untuk spesimen dengan serat gelas setelah dilakuakan uji kekuatan impact pada serat dengan panjang $4 \mathrm{~cm}$ didapat kekuatan impactnya sebesar $3593,333 \mathrm{Kj} / \mathrm{m}^{2}$. ini Seperti terlihat pada gambar 4.8 bahwa kekuatan impact serat dengan panjang $5 \mathrm{~cm}$ lebih tinggi dari pada serat $4 \mathrm{~cm}$. ini dikarenakan pada spesimen ini menggunakan serat yang lebih pendek sehingga kemampuan serat dalam menerima beban yang diberikan oleh matrik akan lebih lemah, dan tingkat elastisitas serat yang pendek lebih lemah dibandingkan dengan yang panjang.

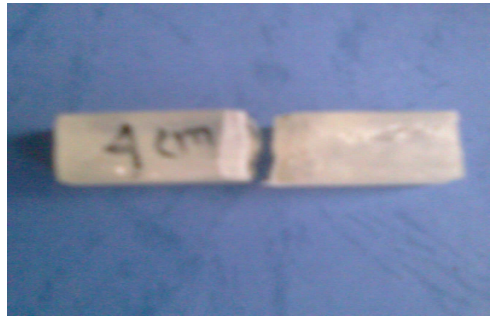

Gambar 4.13. Foto makro hasil uji impact dengan panjang serat $4 \mathrm{~cm}$

Selanjutnya, dari hasil uji kekuatan impact pada serat gelas dengan panjang serat $5 \mathrm{~cm}$ dengan arah serat acak didapat besar kekuatan rata-rata impactnya adalah 5553,333 $\mathrm{Kj} / \mathrm{m}^{2}$. Ini merupakan hsil uji kekuatan impact dengan daya serap energi yang paling tinggi dari pada serat yang lebih pendek, dan ini juga dikarenakn jumlah void pada spesimen ini tidak ada. Dan tingkat elastisitas dari spesimen akan lebih tinggi dalam menerima beban.

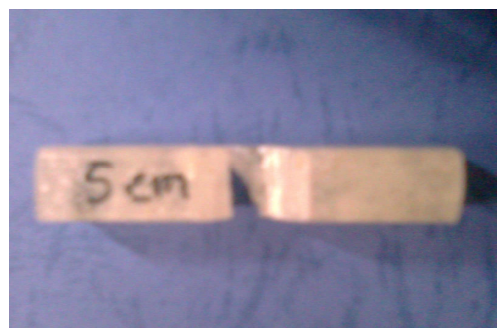

Gambar 4.14 Foto makro hasil uji impact dengan panjang serat $5 \mathrm{~cm}$ 
Dari hasil pengujian kekuatan impact untuk variasi panajng serat didapat bahwa kekuatan impact komposit serat gelas 13,75 \% lebih tinggi dibandingkan dengan serat pandan wangi. ini dikarenakan permukaan serat gelas lebih kasar sehingga daya rekat antara serat dengan matrik lebih sempurna. Lain halnya dengan komposit serat pandan wangi permkuaan seratnya lebih licin. Ini disebabkan oleh sisa-sisa zat lilin (lignin) yang masih menempel pada permukaan serat. Zat lilin pada permukaan serat akan mengurangi daya rekat resin polyester sebagai matrik komposit akan menurun. Karena permukaan yang baik terdapat pada tinggakat kekasaran dari serat itu sendiri sehingga menyatunya serat dengan polyester lebih baik.

\section{Hasil Uji Kekuatan Bending}

Dilihat pada gambar dibawah ini, Pada gambar B merupakan specimen dengan serat gelas, kekuatan bendingnya lebih tinggi dari pada Gambar A, yang seratnya dari pandan wangi. Pada specimen dengan serat gelas memerlukan beban yang lebih besar untuk terjadinya patah. Ini menujukkan bahwa kekasaran permukaan serat juga mempengaruhi kekuatan specimen itu sendiri. Dilihat pada gambar A dengan serat pandan wangi terjadinya lendutan yang tinggi sebelum terjadi patah. Ini menujukkan tingkat lendutan sebelum patah, specimen pandan wangi lebih tinggi dari pada serat gelas.

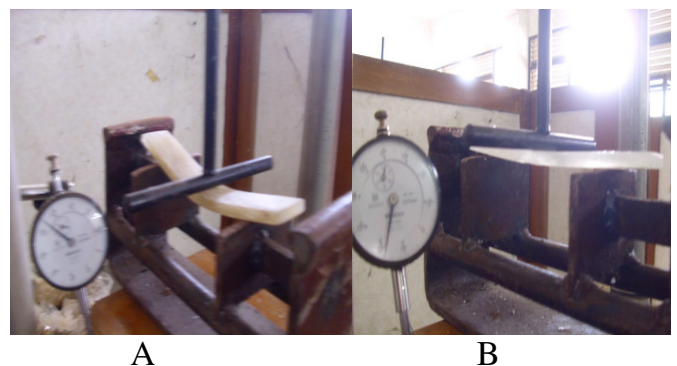

Gambar 4.15. spesimen uji kekuatan bending dengan komposit serat gelas dan komposit serat pandan wangi.

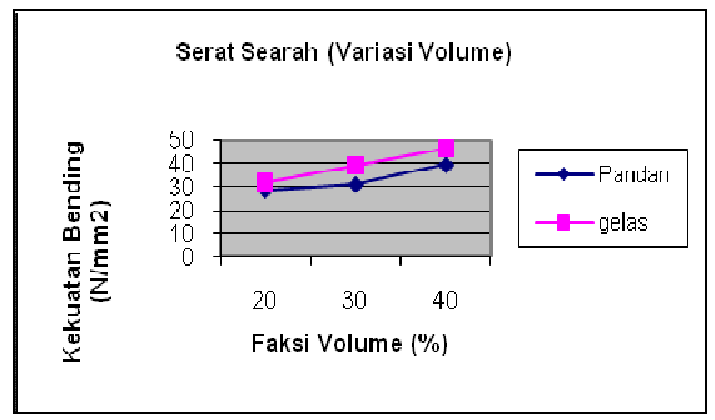

Gambar 4.16. Grafik hubungan kekuatan bending dengan varisi volume serat komposit serat gelas dan komposit pandan wangi.

Dari gambar diatas dilihat bahwa semkin bertambahnya volume serat yang dipakai maka kekuatan bendingnya akan semakin meningkat. Dari hasil pengujian diatas didapat kekuatan bending yang paling rendah pada specimen dengan menggunakan serat pandan wangi pada volume serat $20 \%$ sebesar $171,76 \mathrm{KN}$. Ini dikarenakan kurangnya serat yang digunakan. sehingga kemampuan serat untuk menahan beban yang diberikan oleh matrik akan berkurang, dan selain itu juga pada specimen dengan volume serat $20 \%$ terdapat banyak ruang kosong yang belum terisi oleh serat, disebabkan kurangnya serat yang dipakai. Sehingga dalam menahan beban yang diberikan juga kekuatan akan berkurang. dilihat pada bentuk patahan setelah di lakukan pengujian specimen terlihat lebih getas dikarenakn kurangnya serat yang digunakan.

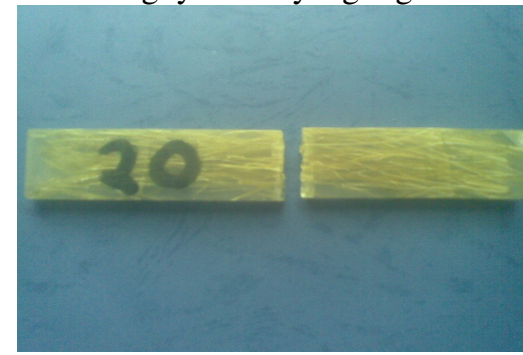

Gambar 4.17. Foto makro hasil uji bending dengan volume serat $20 \%$

Sedangkan pada volume serat $30 \%$ seperti dilihat pada gambar 4.16 bahwa kekutan bending semakin meningkat. ini dikarenakan jumlah void lebih sedikit dan jumlah serat yang digunakan lebih banyak sehingga lebih mampu dalam menahan beban. dilihat dari bentuk patahanya terlihat adanya serat ini menandakan kekuatan dan elastisitas dalam menahan beban lebih tinggi, dan bentuk spesimenya keliatan lebih padat.

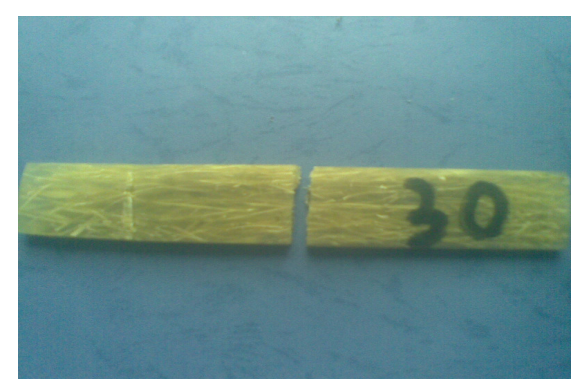

Gambar 4.18 Foto makro hasil uji bending dengan volume serat $30 \%$

Selanjutnya dari gambar 4.16 juga dijelaskan bahwa kekuatan paling tinggi didapat pada volume serat 
$40 \%$ sebesar 236,67 KN, ini disebabkan semakin banyak serat yang digunakan maka kekuatan dalam menerima beban akan semakin tinggi, pada spesimen ini tidak ada terjadinya void yang juga besar pengaruh terhadap kekuatan dari spesimen. Sepesimen dengan volume serat $40 \%$ tingkat elastisitasnya lebih tinggi sehingga kekutannya juga akan lebih tinggi dibandingkan dengan spesimen dengan volume serat $20 \%$, dan $30 \%$. dari bentuknya juga kelihatan bahwa spesimenya lebih ulet dan padat, sehingga kemungkinan untuk bergesernya serat sangat sedikit.

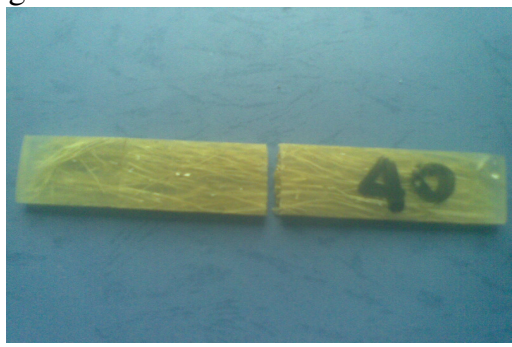

Gambar 4.19 Foto makro hasil uji bending dengan volume serat $40 \%$

Dari gambar 4.16 dilihat untuk hasil uji kekuatan bending pada spesimen serat gelas dengan volume serat 20\% didapat kekuatan bendingnya sebesar 190 $\mathrm{KN}$ disini terjadi penurunan kekuatan. Ini dikarenakan sedikitnya serat yang digunakan dalam menahan beban yang diberikan oleh matrik sehingga kemampuan dari jumlah serat akn menurun dikarenakan seart yang diguna sangat sedikit. Seperti terlihat pada gambar dibawah ini setelah spesimen dilakuakan pengujian terlihat lebih getas, ini menandakan kalau kekuatan spesimen dengan volume serat $20 \%$ dalam menahan beban lebih rendah dibandingkan dengan spesimen pada volume serat yang lebih tinggi. Selain itu juga kemungkinan akan terjadi pergeseran serat waktu menahan beban, sehingga pada saat diberikan beban kekuatan dari spesimen akan berkurang.

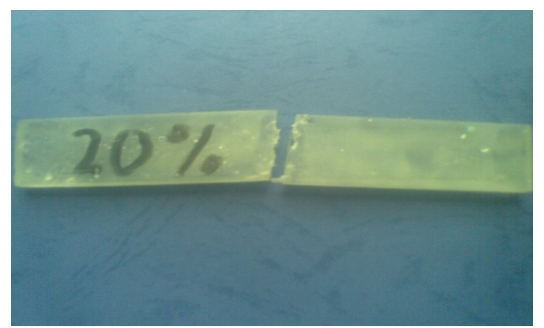

Gambar 4.20 Foto makro hasil uji bending dengan volume serat $20 \%$

Sedangkan Pada volume serat 30\% didapat kekuatan bendingnya sebesar $235 \mathrm{KN}$, pada spesimen volume serat 30 kekuatan bendinganya meningkat, ini dikarenakan serat yang digunakan lebih banyak, jadi kekuatan untuk menahan beban lebih kuat dari pada spesimen dengan volume serat $20 \%$, dan dilihat dari bentuk fisik spesimen terlihat lebih padat dan ulet dikarenakn serat yang digunakan lebih banyak.

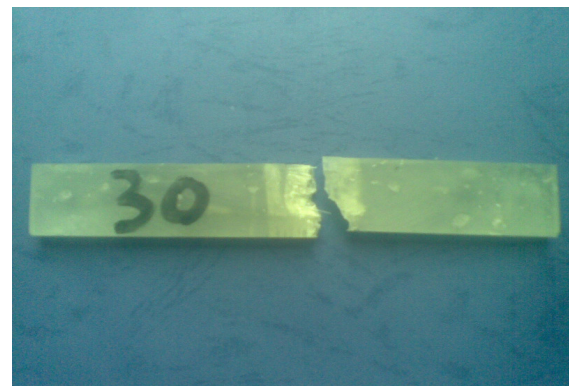

Gambar 4.21. Foto makro hasil uji bending dengan volume serat $30 \%$

Selanjutnya pada komposit serat gelasseperti dilihat pada gambar 4.16 hasil pengujian pada volume serat $40 \%$ kekuatannya sebesar 278,333 KN. kekutan bendingnya lebih tinggi dibandingkan dengan volume serat $20 \%$ dan $30 \%$, dikarenakan banyaknya serat mempengaruahi kuatanya dalam menahan beban yang diberikan, dan kemungkinan void yang terjadi sangat kecil, itu sebabnya kenapa volume serat yang lebih banyak akan lebih kuat dari pada volume serat yang lebih sedikit. Seperti terlihat pada gambar hasil pengujian spesimen dibawah ini spesimenya tidak sampai patah yang terpiash dikarenakn serat yang ada pada spesimen masih begitu kuat dalam menahan beban.

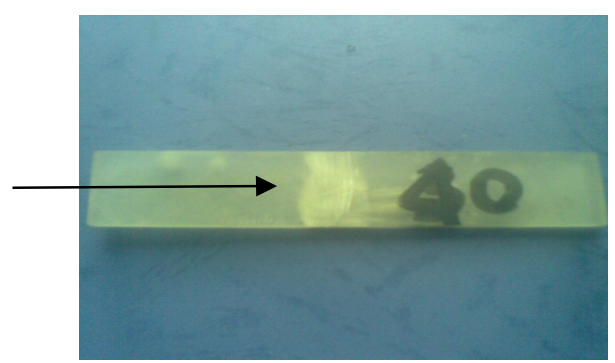

Gambar 4.22 Foto makro hasil uji bending dengan volume serat $40 \%$

Dari hasil uji kekuatan bending untuk komposit serat gelas dan komposit pandan wangi dengan variasi volume serat dengan arah serat searah.bahwa kekuatan serat pandan wangi lebih rendah dibanding komposit serat gelas. ini dikarenakan permukaan dari serat pandan wangi masih terdapat sisa-sisa zat lilin (lignin) yang menyebabkan polyester tidak bisa menempel dengan sempurna pada serat pandan wangai. Permukaan yang kasar akan menyebabkan kekuatan, keuletan, dan tingkat elastisitas serat akan lebih sempurna. Kekuatan serat gelas 7,6 \% lebih kuat dari pada serat pandan wangi. 


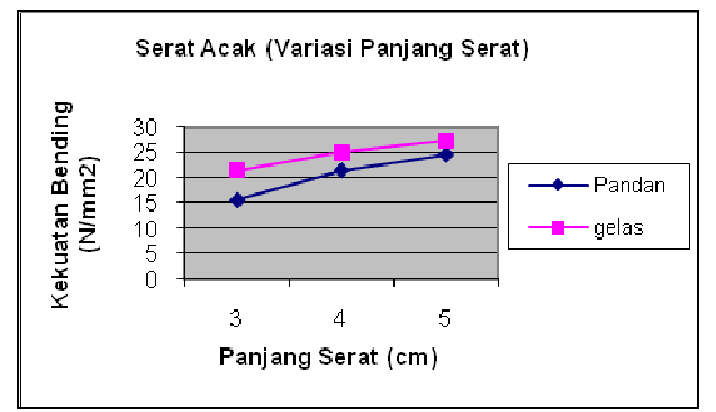

Gambar 4.23. Grafik hubungan kekuatan bending dengan varisi panjang serat komposit serat gelas dan komposit pandan wangi.

Dari hasil pengujian kekuatan bending dilihat pada gambar 4.23 diatas bahwa kekuatan paling rendah didapat pada panjang serat $3 \mathrm{~cm}$ dengan besar keuatan bending 93,334 KN. Ini terjadi karena serat yang dipakai lebih pendek, karena serat yang pendek tingkat kelenturannya rendah sehingga waktu diberikan beban cepat sekali mengalami patah. dilihat pada hasil patahan spesimen terlihat lebih getas. Ini menandakan kekuatan serat yang pendek lebih rendah dibanding serat yang lebih panjang.

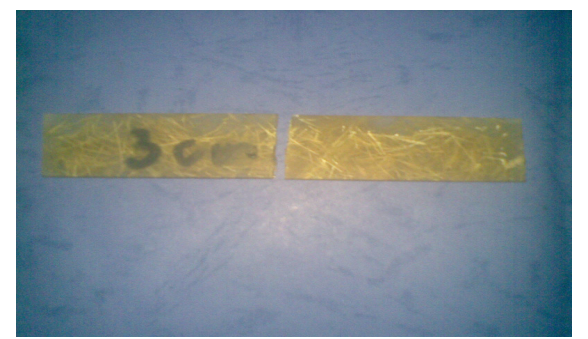

Gambar 4.24 Foto makro hasil uji bending dengan panjang serat $3 \mathrm{~cm}$

Selanjutnya untuk hasil kekutan bending pada panjang serat $4 \mathrm{~cm}$ pada komposit serat pandan wangai mengalami peningkatan kekuatan sebesar 128,34 KN. Salah satu penyebab meningkatnya kekuatan karena serat yang digunakan lebih panjang, dan tidak adanya void yang menyebabkan kekuatan spesimen akan semakin rendah. Seperti dilihat pada gambar dibawah ini. Spesimen keliatan lebih padat, dan pada patahannya ada serabut serat, ini menandakan serat yang lebih panjang kekuatan dalam menerima beban akan semakin kuat.

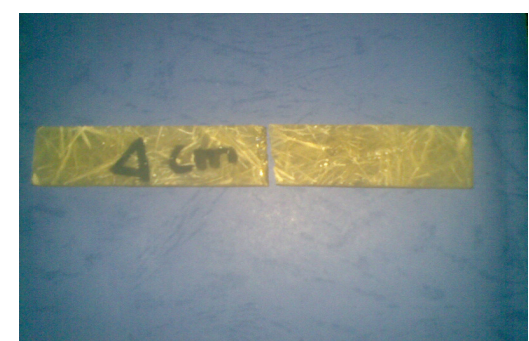

Gambar 4.25 Foto makro hasil uji bending dengan pajang serat $4 \mathrm{~cm}$

Dari gambar 4.16 juga didapat untuk hasil uji kekuatan bending didapat hasil tertingi pada panjang serat yang paling panjang yaitu $5 \mathrm{~cm}$ sebesar $146,667 \mathrm{KN}$. salah satu penyebabnya karena jumlah serat yang menggumpal pada saat diaduk lebih banyak sehingga kemampuan untuk menahan beban juga akan semakin kuat karena banyaknya serat yang saling mengikat satu sama lain. Sealin itu juga serat yang digunakan pada spesimen ini diameternya lebih besar dan permukaan seratnya lebih lebar.

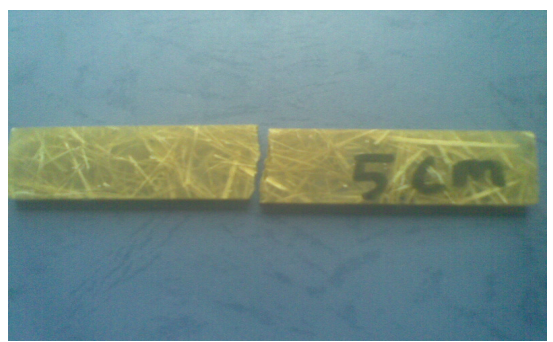

Gambar 4.26. Foto makro hasil uji bending dengan panjang serat $5 \mathrm{~cm}$

Dari hasil pengujian kekuatan bending pada spesimen dengan serat kekuatan paling rendah didapat pada panjang serat $3 \mathrm{~cm}$ sebesar 128,34 KN. Ini dikarenakan panjang serat yang digunakn. Karena semakin panjang serat, maka kekuatan untuk menerima beban akan lebih sempurna. Pada spesimen dengan panjang serat yang lebih pendek, dan arah serat yang digunakan acak kekutanya rendah, ini juga dikarenakan pada waktu pengadukan serat dengan polyester sebagai perekat tidak terjadi gumpalan yang berlapis-lapis sehingga bentuk serat pada spesimen keliatan lebih tipis kekutan juga rendah.

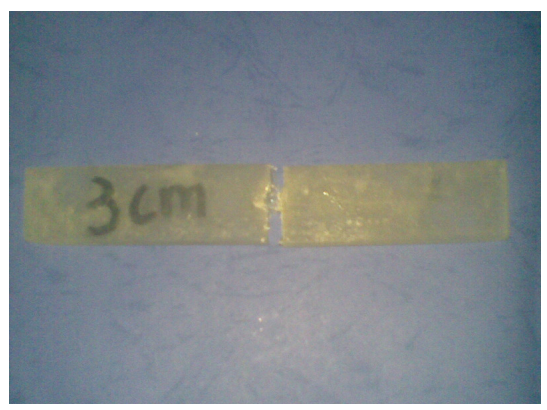


Gambar 4.27 Foto makro hasil uji bending dengan panjang serat $3 \mathrm{~cm}$

Dari gambar 4.16 diatas pada hasil uji kekuatan bending pada komposit serat gelas dengan panjang serat $4 \mathrm{~cm}$ dengan kekuatan menahan beban bending sebesar $150 \mathrm{KN}$. bila dibandingkan dengan spesimen dengan panjang serat $5 \mathrm{~cm}$ terlihat kekuatan sepsimennya lebih tinggi. Ini dikarenakan selain karena kemapuan serat yang kurang lentur dalam menahan beban, ini juga disebabkan karena pada saat pengdukan atapun pencampuran serat dengan resin polyester jumlah tumpukan seratnya lebih sedikit dari pada serat dengan panjang $5 \mathrm{~cm}$

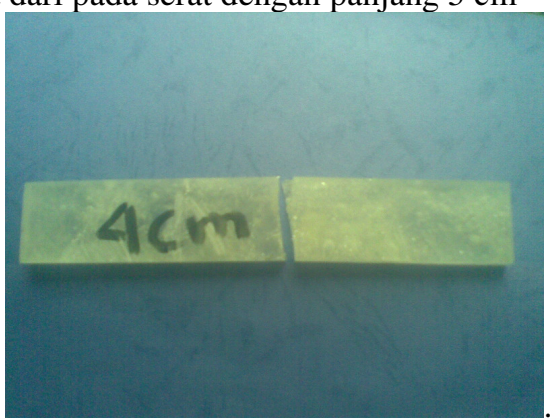

Gambar 4.28 Foto makro hasil uji bending dengan panjang serat $4 \mathrm{~cm}$

Selanjutnya dari gambar 4.16 diatas dilihat hasil uji kekuatan bending yang paling tinggi didapat pada spesimen dengan panjang serat $5 \mathrm{~cm}$ sebesar 163,334 KN. dari gambar 4.29 dapat dilihat pada bidang patahan bendingnya. Spesimen dengan serat gelas 5 cm tidak smapai putus pada waktu diuji kekuatan bendingnya, ini dikarenakan keuletan dari spesimen dengan menggunakan serat yang lebih panjang keuletannya lebih tinggi. kalau spesimen dengan serat yang lebih panjang ini akan lebih mampu mengikat antara serat yang satu dangan yang lain dengan lebih sempurna.

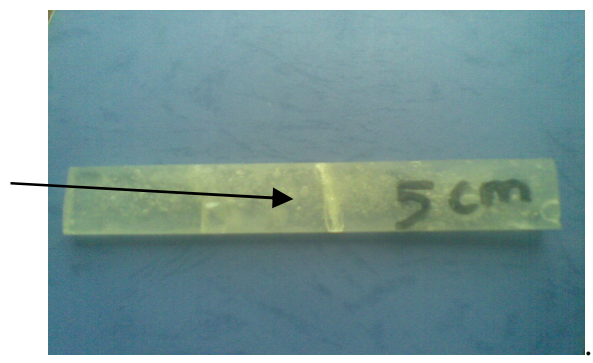

Gambar 4.29. Foto makro hasil uji bending dengan panjang serat $5 \mathrm{~cm}$

Dari hasil pengujian kekuatan bending diatas bahwa untuk komposit serat gelas dan komposit pandan wangi dengan variasi panjang serat dengan arah serat acak, didapat kekuatan paling tinggi pada panjang serat $5 \mathrm{~cm}$. dan kekuatan bending terendah didapat pada panjang serat dengan panjang $3 \mathrm{~cm}$, ini dikarenakan semakin pendek serat yang digunakan maka el akan berkurang untuk menerima beban yang diberikan,dan semakin pendek serat yang dipakai kemungkinan akan terjadinya void akan semkin besar, inilah salah satu alasan kanapa serat yang lebih pendek lebih rendah kekuatnya dibandin dengan serat yang lebih panjang.

Selain itu juga pada hasil uji kekuatan bending komposit serat panadan wangi dan komposit serat gelas. Bahwa kekuatan komposit serat gelas 8,7 \% lebih tinggi dibandingkan dengan serat pandan wangi. ini dikarenakan kekasaran permukaan serat gelas lebih tinggi dari serat pandan wangi, tingkat kekasaran permukaan serat akan membuat daya rekat resin polyester sebagai matrik komposit akan meningkat.sehingga penyatuan antara serat dengan resin atau matrik akan lebih sempurna. Dan ikatan yang baik ditandai dengan tidak adanya serat yang tercabut dari matriknya. Ini terlihat pada hasil uji kekuatan bending pada spesimen dengan serat gelas.

\section{Hasil Perhitungan Uji Impact Dengan Menggunakan Metode Anova}

Dari tabel analisis anova diatas ditunjukkan bahwa $F_{\text {hitung }}>F_{\text {tabel }}$, yaitu 52,59541098 $>$ 4,747 maka Ho ditolak sehingga Volume serat berpengaruh signifikan terhadap kekuatan impat komposit serat pandan wangi dan serat gelas dengan matrik polyester. Sedangkan untuk jenis serat bahwa didapat $F_{\text {hitung }}<F_{\text {tabel }}$ yaitu $0,6194690264<3,885$ maka Ho diterima sehingga jenis serat tidak berpengaruh signifikan terhadap kekuatan impact komposit serat gelas maupun serat pandan wangi.

\section{A. Hasil Perhitungan Kekuatan Impact Pada Komposit Serat Pandan Wangi Dan Serat Gelas Dengan Variasi panjang Serat (cm) Dengan Arah Serat Acak}

Tabel 3. Hasil perhitungan $\mathrm{F}_{\text {hitung }}$ kekuatan impact dengan variasi volume serat (\%) 


\begin{tabular}{|c|c|c|c|c|c|}
\hline Sumber Variasi & DK & JK & MK & Fh & F\% \\
\hline Jenis Serat & 2 & $14.192 .577,78$ & $7.096 .288,889$ & 0,6194690264 & 3,885 \\
\hline Volume Serat & 1 & 682.503 .458 & 682.503 .458 & 52,59541098 & 4,747 \\
\hline Error & 12 & $137.465 .253,3$ & $11.455 .437,78$ & & \\
\hline Total & 15 & $83.416 .288,9$ & & & \\
\hline
\end{tabular}

Dari tabel analisis anova diatas ditunjukkan bahwa $\mathrm{F}_{\text {hitung }}>\mathrm{F}_{\text {tabel, }}$ yaitu 52,59541098 $>$ 4,747 maka Ho ditolak sehingga Volume serat berpengaruh signifikan terhadap kekuatan impat komposit serat pandan wangi dan serat gelas dengan matrik

polyester. Sedangkan untuk jenis serat bahwa didapat $\mathrm{F}_{\text {hitung }}<\mathrm{F}_{\text {tabel }}$ yaitu $0,6194690264<3,885$ maka Ho diterima sehingga jenis serat tidak berpengaruh signifikan terhadap kekuatan impact komposit serat gelas maupun serat pandan wangi.

\section{B. Hasil Perhitungan Kekuatan Impact Pada Komposit Serat Pandan Wangi Dan Serat Gelas Dengan Variasi panjang Serat (cm) Dengan Arah Serat Acak}

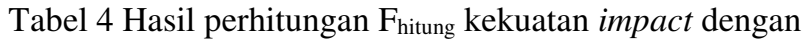
variasi panjang serat $(\mathrm{cm})$

\begin{tabular}{|c|c|c|c|c|c|}
\hline Sumber Variasi & DK & JK & MK & Fh & $\begin{array}{c}\text { Ftabel } \\
5 \%\end{array}$ \\
\hline Jenis Serat & 2 & 111.106 .800 & 55.553 .400 & 26,88710273 & 3,885 \\
\hline Panjang Serat & 1 & $23.759 .022,22$ & $23.759 .022,22$ & 11,49902127 & \multirow{2}{*}{4,747} \\
\cline { 1 - 5 } Error & 12 & $24.791 .133,73$ & $2.066 .172,778$ & & \\
\hline Total & 15 & 1.596 .569 .556 & & & \\
\hline
\end{tabular}

Dari tabel analisis anova diatas ditunjukkan bahwa untuk jenis serat dan panjang serat bahwa $\mathrm{F}_{\text {hitung }}<$ $F_{\text {tabel}}$, yaitu untuk jenis serat $26,88710273>3,885$ dan panjang serat $11,49902127>4,747$ maka Ho ditolak sehingga jenis serat dan panjang serat berpengaruh signifikan terhadap kekuatan impat komposit serat pandan wangi dan serat gelas dengan matrik polyester.

\section{Data hasil perhitungan kekuatan bending pada komposit serat pandan wangi dan serat gelas dengan Variasi panjang serat $(\mathrm{cm})$ dengan arah serat acak}

Tabel 5 hasil perhitungan uji kekuatan bending komposit serat pandfan wangi dan komposit serat gelas dengan Variasi panjang serat $(\mathrm{cm})$.

\begin{tabular}{|l|l|l|l|l|l|}
\hline Sumber Variasi & DK & JK & MK & Fh & $\begin{array}{l}\text { Ftabel } \\
5 \%\end{array}$ \\
\hline Jenis Serat & 2 & $6.008,3333$ & $3.004,16667$ & 1,78440808 & 3,885 \\
\hline panjang Serat & 1 & $2.688,889$ & $2.688,889$ & 1,59714011 & 4,747 \\
\hline Error & 12 & $20.202,78$ & $1.683,36481$ & & \\
\hline Total & 15 & $28.900,0023$ & & & \\
\hline
\end{tabular}

Dari tabel analisis anova diatas ditunjukkan bahwa $\mathrm{F}_{\text {hitung }}<\mathrm{F}_{\text {tabel, }}$, jenis serat yaitu $1,59714011<4,747$ dan panjang serat yaitu $1,78440808<3,885$ maka Ho diterima sehingga variasi panjang serat dan jenis serat tidak berpengaruh signifikan terhadap kekuatan impat komposit serat pandan wangi dan serat gelas dengan matrik polyester. 
D. Hasil Perhitungan Kekuatan bending Pada Komposit Serat Pandan Wangi Dan Serat Gelas Dengan Variasi Volume Serat (\%).

Tabel 6 Hasil Perhitungan Uji Kekuatan bending Komposit serat pandan wangi dan Serat Gelas Dengan Variasi volume Serat (\%)

\begin{tabular}{|l|l|l|l|l|l|}
\hline Sumber Variasi & DK & JK & MK & Fh & $\begin{array}{l}\text { Ftabel } \\
5 \%\end{array}$ \\
\hline Jenis Serat & 2 & $17.911,1111$ & $8.955,55555$ & 2,834701136 & 3,885 \\
\cline { 1 - 5 } Volume Serat & 1 & $5.868,056$ & $5.868,056$ & 1,857415201 & 4,747 \\
\cline { 1 - 4 } Error & 12 & $37.911,11$ & $3.159,259167$ & & \\
\hline Total & 15 & $61.690,2771$ & & & \\
\hline
\end{tabular}

Dari tabel analisis anova diatas ditunjukkan untuk jenis serat bahwa $F_{\text {hitung }}<\mathrm{F}_{\text {tabel }}$, yaitu $1,857415201<$ 4,747 seadangkan untuk variasi volume serat $2,834701136<3,885$ maka Ho diterima sehingga tidak berpengaruh signifikan terhadap kekuatan bending komposit serat pandan wangi dan serat gelas dengan matrik polyester

\section{Kesimpulan}

Dari hasil peneltian, pengujian dan pembahasan hasil uji yang telah dilakukan maka dapat ditari kesimpulan antara lain :

1. Pada material komposit serat pandan wangi polyester dan serat gelas polyester menunjukkan bahwa, semakin panjang serat yang digunakan maka kekuatan impactnya juga semakin meningkat. Begitu juga dengan kekuatan impact pada variasi fraksi volume serat bahwa semakin besar volume serat yang digunakan kekuatan impact dari kedua jenis komposit juga akan semakin meninggkat

2. Pada material komposit serat pandan wangi polyester dan komposit serat gelas polyester menunjukkan bahwa semakin panjang serat yang digunakan kekuatan bending dari dua jenis komposit akan semakin meninggkat. Begitu juga dengan variasi volume serat, semakin besar volume serat yang digunakan kekuatan bendingnya juga akan semakin meninggkat.

3. Berdasarkan metode anova menujukkan bahwa pada variasi panjang serat dan variasi volume serat yang digunakan bahwa berpengaruh secara signifikan terhadap kekuatan impact. Sedangkan untuk variasi fraksi volume serat dan variasi panjang serat didapat hasil bahwa kekuatan tidak berpengaruh besar terhadap kekuatan bending yang digunakan.

4. Secara teoritis didapat bahwa tegangan tarik maksimum serat ( $\sigma$ mak) pada spesimen uji bending pada kulit terluar komposit, didapat omak: sebesar 55226,2 Mpa. Sedangkan kekuatan tarik serat besarny 39,072 Mpa. Ini menunjukkan bahwa kekuatan serat pada spesimen uji bending jauh lebih kuat dibanding dengan hanya seratnya saja. 


\section{Daftar Pustaka}

1. Han, Kyung S. 1984,'The Interlaminar Frakture Energy of Glass Fiber Reinforced Polymer Composite". Glass Reinforced Polymer System, Laucaster Pennsylvania : Technomis Publishing Co. Inc

2. ASTM ( 2003 ) D 256 Standard Test Methods for Void Content of Reinforced Plastics. ASTM Internasional, USA.

3. Jamasri, Diharjo, K, Handiko, G. W. (2005), Studi Perlakuan Alkali Terhadap Sifat Tarik Komposit Limbah Serat Sawit - Polyester, Prosiding Seminar Nasional Tahunan Teknik Mesin IV, Universitas Udayana, Bali.

4. Lokantara Putu, Suardana, N P G, (2007), Analisis Arah dan Perlakuan Serat Tapis Serta Rasio Epoxy Hardener Terhadap Sifat Fisis dan Mekanis Komposit Tapis/Epoxy, Jurnal Ilmiah Teknik Mesin Cakram Vol. 1 No. 1, (15-21).

5. Mohan Rao, K.M., and Mohana Rao, K., (2005), Extraction and tensile properties of natural fibers : Vakka, date and bamboo, Elsevier, Composite structures.

6. Oksman, K., Skrifvars, M., Selin, J-F., (2003), Natural Fiber as Reinforcement in Polylactic Acid (PLA) Composites, Composites Science and Technology 63, Sciencedirect.com, 1317-1324.

7. Suardia, T, Saito, S. (1985). Ilmu Pengetahuan Bahan Teknik, Pradnya Paramita Jakarta.

8. Satyanarayana, K. G., dkk (1982), Structure Property Studies of Fibres From Various Parts of The Coconut Tree. Journal of Material Science 17, India
9. Taurista, A.Y, Riani, A.O, Putra, K.H. (2003), Komposit Laminat Bambu Serat Woven Sebagai Bahan Alternatif Pengganti Fiber Glass Pada Kulit Kapal. ITS, Surabaya..

10. Wr Wijang, Ariawan Dody, (2006), Pengaruh Modifikasi Serat Terhadap Karakteristik Komposit UPRs Cantula, Jurnal Teknik Mesin Poros Volume 9 Nomer 3, ( 200-206 ).

11. Paris D.C and Erdogen F. 1963,"Critical Analysis of Crack Propagation Laws", Transactions of ASME, Journal of Basics Engineering, $85,528-534$

12. Sun, C.T and Sierakowski, R.L. 1980,"Frakture Characterization of Composite of Chopped Fiber Glass Reinforcement", SAMPE Quarterly, 11 (4), 2-15

13. Whitney, J.M and Hoogsteden, W. 1992,"Double Cantilever Beam Test for Characteristizing Mode I Delamination of Composite Material", Journal of Reinforced Plastics and Composite, vol 1, 297-313

14. Harrison N.L, 1972,"Strain Energy Release Rate for Turning Crack", Fiber Sci. Teknol. 5, 197-212

15. Sih G.C, 1973,"A Special Theory of Crack Propagation", in Metode of Analysis and Solution of Crack Problem, Mechanic of Fracture I pp.XXI-XLV, Noordhoff Int. publ. The Nederland.

16. O'Brien, T.K, 1982,"Characterization of Delamination Onset and Growth in a Composite Laminate", in K.L Refsnider (ed), Damage in Composite Material, ASTM STP. 775, 140-167, American Society for Testing Material, Philadelphia, PA 